\title{
Learning Stillness: AIDS and the Straight Female Caregiver
}

\author{
Tanis MacDonald
}

\begin{abstract}
Apprendre la maladie: le sida et une straight dévouée
Dans ce témoignage, Tanis MacDonald s'interroge sur le cliché de la «straight» quifait son entrée dans la communauté gaie par amour pour un de ses membres. Cet homme l'encourage à laisser libre cours à sa sexualité et à aller au-delà des limites imposées par la société. Par contre, la problématique du sida arrivant dans le décor, elle se retrouve dans une position qui l'oblige à rejeter l'indifférence générale des hétérosexuels à l'encontre des sidéens pour devenir l'exemple parfait d'une jeune fille s'exerçant au dévouement. Cette femme prend soin de ses amis les plus proches qui meurrent pourtant les uns après les autres. Et bien que son affiliation avec la "nation" ne soit pas évidente en soi, elle tient à en faire partie parce qu'il n'existe pour elle aucun autre endroit où son chagrin pourrait être partagé. Comme MacDonald le réalise plus tard, son besoin de faire partie d'une communauté avec laquelle elle peut pleurer la mort de ses meilleurs amis tient d'un effort frénétique à prouver qu'en fait elle est, elle aussi, une martyre. Mais cette «empathie»l'amène bientôt au burnout et finit par la paralyser. «Apprendre l'immobilité» c'est, pour MacDonald, une voie qui permettrait unealternative à la fois au martyred'une "gentille fille faisant pénitence pour son amour», et à unétat paralysant.
\end{abstract}

I have worked in the HIV community since 1987. I'm not a nurse. I'm not a lesbian. I have no husband or child with AIDS. I am not HIV+. I began by believing that my only motivation was an altruistic desire to help in a crisis, but that belief bit the dust during my first stint on an AIDS careteam. No, I had an ulterior motive in working with people with AIDS. I did it to busy myself in the face of terror, so that one day, I would be able to glance up from a horrific task, look fear in the eye, and briskly go about my business. Fast footwork. I did it to intimidate myself out of paralysis.

Straight white women from the suburbs don't figure prominently in HIV organizations. I've traversed North America leading workshops, 
and proportionally, our percentages are low in this community. But we are present. I was asked once what it felt like to be a walking cliche, which I thought was unfair, but I now understand what was meant. Straight women are usually drawn into the HIV community by our love for a gay man. Someone who encouraged us to be sexual, who laughed at our jokes, who was a scream to shop with. Some gay man we loved, a relationship that was always hard to explain to our parents or boyfriends, or to other women. We didn't correct people who thought we were a couple; he got a tenuous kick out of passing for straight. To her, they were a couple, everywhere but the bedroom. We took advantage of this ability to pass in small public ways, demanding the restaurant's best table because it was our 'anniversary,' holding hands in the street, keeping an arsenal of private jokes at which to shriek and snort. Intimate rituals that harmed no one. Then there was AIDS.

Now those rituals scared us. Many of us hadn't yet witnessed our parents' deaths, and now our pseudo-boyfriends were dying, turning into old men in zippered cardigans almost overnight. Some women say that they never felt as close to their husbands or lovers as to that one special gay man. Put any Freudian spin on it you want. Love is love, and a narrow society often overlooks the strength of bonds between two people.

With the onset of AIDS, our choices were few: Be There or Get Out. Not that these choices were ever articulated to me in such stark terms, but I knew that sticking around meant changing the friendship. Maybe it wasn't such a big leap; caregiving is a service women are raised to emulate. Our grandmothers cared for the sick and elderly. A part of me was well-versed in care, no matter how much I professed ignorance. And to my surprise, it didn't immobilize me. Until recently. In my eighth year in the community, after leading countless wellness seminars for PWAs, after memorizing multi-lettered medications and conditions, after serving on several careteams, after being questioned about my presence and politics and sexual orientation, I stopped.

My initial investment in this community ended up being my most exhausting commitment. Wilf and John, my friends for thirteen years, were gay men who encouraged me to wear spike heels, to move to the Big City, to be more than a nice girl. I won't hold up our friendship as sacred; it wasn't holy or perfect, but when the three of us met in university, I didn't expect to attend both their funerals before my thirty-third birthday. 
Wilf died first, in 1993, after living seven years longer than any doctor predicted. By that time, I was working in the HIV community and I swore I was dealing with AIDS in my world as well as possible, but Wilf's death tumbled that house of cards, and when John died 15 months later from HIV-complicated cirrhosis, a door shut somewhere inside me, and I said, no more. Most people called it burnout, but it felt different, heavier, as if paralysis settled into my bones with a dense and daunting weight.

I could not watch anyone else die. I took a sabbatical from my leadership post with an organization that promotes living powerfully with AIDS. It became very clear to me that I was no longer the best person to convey a hopeful message. Too much doubt glazed my eyes. I no longer believed in what I was counselling others to try. I no longer had a view to anyone else's grief but my own. In short, I became one of those people for whom I used to harbour just the slightest, archest contempt: someone who says she just can't handle being with people with AIDS "because it's just too intense...."

Straight white women from the suburbs: our guilt over privilege, our need for love, our need for the control that caregiving seems to grant. What a mess. My growing isolation from a community in which I invested so much is painful but welcome. The longer I stay away, the less I want to return. I admitted this to the one HIV + friend I dare keep in my life, and I fully expected him to heap scorn on my selfish statement. Instead, he was sympathetic, and said he would do the same, if he could. But he can't.

Since leaving the community, I feel an increased awareness of my former position in it. It felt exactly like going dancing with John and Wilf in the mid-eighties at gay clubs downtown. I put on something tight and flashy that the boys picked out for me, an outrageous outfit I would never choose on my own, and we shimmered through the dark streets to a basement with watery drinks and flashing lights, sweaty men crowding the grimy dance floor, gyrating and stomping their polished cowboy boots. Nobody ever thought my outfit was wild. Nobody mistook me for a lesbian. I looked like a straight suburban white chick. I was.

The boys fit in, strutting, passing amyl nitrate and laughing, bright shirts like plumage, tight pants showing off crotch and ass. I only caught an edge of the culture: I knew there was more, stuff the boys told me happened after hours or in the bathroom, and stuff they didn't tell me at all. I knew I didn't belong here, although I was made welcome, although the boys begged me to come with them. 
Their two deaths have stopped me most of all, they who drew me into risking my heart at the beginning. I consider my life with awe. It seems an impossibly fabulous and unmanageable gift now, like an elephant delivered to my backyard overnight. It's amazing, it's valuable, but the care and feeding? The broader purpose? I am nonplussed.

There is an odd dynamic to being a minority within a special-interest group, particularly when that minority is used to being, in the larger population, a part of the majority. I always felt a need to do more to be allowed a place in the HIV community. I grieved as fast as I could. Sometimes I chose to be too busy to grieve at all. I admired the other women in the community, particularly the lesbians, whom I viewed with haloes of political astuteness. Their strength and dedication to feminism and social justice awed me. Many women, straight and lesbian, held leadership positions in the HIV community: I did not lack for female role models. If fact, almost every woman I knew in the community was a leader: a dozen or more Mother Courages, and precious few female foot soldiers. But in the Brecht play, all of Mother Courage's children die. I can't remember what happens to her at the end: I think she carries on, searching for endless war, because her strength is her survival and that's all she has left.

It's ironic; a small world of strong women and sensitive men was a societal reversal I always thought I wanted to see. It fit my feminist vision of personal choice, a community where people could choose their way of life, and what they chose was often the behaviour that was not culturally sanctioned for their gender in the larger world. A small world where men could weep, and where women were applauded for their anger and political savvy.

Like those late nights at the dance clubs, I was at once a part of the gay and lesbian community and apart from it. I was an emissary from QueerNation to the straight world - a messenger to those for whom AIDS was still only a news item. I had an impact. I spoke to groups and individuals, and straight people with HIV or AIDS showed up at my door to be linked with HIV support services that they badly needed. But as years passed, I came to feel my impact was a pebble tossed into an ocean. And with that, grief rained down upon me.

The straight world doesn't react as a community to AIDS, and could not support me in my grief. People tried, but were taken aback by the multiple deaths, the lack of answers, my whole Pandora's box of emotion. The gay community had the resources and the services, but 
their focus was justifiably on the grief and suffering of others. When members of a minority are dying, the emotional angst of the privileged majority takes a backseat.

The intimacy that I shared with many of the gay men was missing between myself and my female colleagues. We respected and admired each other, no question. "How do you do what you? You astound me," I'd say. She'd respond, "ME? What about what you do? I couldn't stand it." We spoke about AIDS, and not much else; not our dreams, aspirations, lovers, not even books or movies. We often remained isolated; women with similar loves and griefs, kept from solidarity by our raging need to keep doing, keep soothing and hugging and talking, massaging feet, cooling brows, writing letters of protest, shouting at rallies and speaking at funerals, listening and nodding and carrying the world upon our shoulders. Nice girls doing penance for our love. So now I have stopped doing. Now I wait: if a door slammed shut inside me after John's death, it has begun to creak open again, just a little. I have discovered a difference between paralysis and stillness. Paralysis is being swallowed by the great gulping maw of fear: stillness is finding peace despite the fear. Stillness is an act of faith infinitely more difficult than doing.

Last week, I spoke to a woman friend about why I no longer work in the HIV community. It was a relief to admit my weaknesses, my need for sanctuary. She nodded; she knew. Two days later, I sat at the bedside of a dying friend, an AIDS counsellor with whom I worked for five years. We talked, he slept, I held his hand. I did nothing else. Remembering the sweetest part: how I chose to expend my love. It helps me keep still. 